\title{
The Relationship Between Religiosity and Smoking Cessation: An Analysis of Indonesian Family Health Survey 2014
}

\author{
Tika Dwi Tama ${ }^{1, *}$ Erni Astutik ${ }^{2,}$ Nurnaningsih Herya Ulfah ${ }^{1,3}$ \\ ${ }^{1}$ Department of Public Health, Faculty of Sport Science, Universitas Negeri Malang, Malang, East Java, Indonesia \\ ${ }^{2}$ Department of Epidemiology, Biostatistics, Population Studies, and Health Promotion, Faculty of Public Health, \\ Universitas Airlangga, Surabaya, East Java, Indonesia \\ ${ }^{3}$ College of Public Health Sciences, Chulalongkorn University, Bangkok, 10330, Thailand \\ *Corresponding author. Email: tika.dwi.fik@um.ac.id
}

\begin{abstract}
Besides having cultural diversity, Indonesia also has diversity in religion. All religion guide their followers to live in goodness and avoid harmful behavior. Smoking is one of harmful behavior that not only affect health but also others aspect in life. In the last five years, one of third population $\geq 15$ years old in Indonesia was smoker. The aim of this study was to determine the relationship between religiosity and smoking cessation in Indonesia. A cross-sectional study was conducted by using secondary data from Indonesian Family Life Survey 2014. As many as 10481 respondents were included in analysis. The association between religiosity and smoking cessation was measured by multiple logistic regression. This study found that the smoking cessation rate was $11.4 \%$. The level of religiosity had a significant association with smoking cessation. Very religious people (aOR 1.99; 95\% CI $1.31-3.02$ ), religious (aOR 1.83; 95\% CI 1.23 - 2.72), somewhat religious (aOR 1.33; 95\%CI $0.8-2.01$ ) had higher odds to quit smoking than not religious. Increasing religious adherence can lead people to adopt better behaviors, including quitting smoking. Using a religious approach in promoting the dangers of smoking could be an effective way.
\end{abstract}

Keywords: IFLS 5, Indonesia, religiosity, smoking cessation

\section{INTRODUCTION}

Smoking or tobacco use is well known as the silent killer. Tobacco kills more than 7 million people each year, more than 6 million of those deaths are the result of direct tobacco use [1]. The morbidity and mortality caused by smoking are progressively increasing in all over the countries $[2,3,4,5]$. In the United States, more than 16 million people having smoking-related diseases, such as cancer, respiratory, and cardiovascular diseases [2]. Smoking is also responsible for one in five deaths annually, which is actually preventable [2]. In Indonesia, $14.7 \%$ of all mortality was caused by tobacco use [3]. It is predicted that the number of smoking-related diseases and deaths continues rising. It could not be apart from the fact that the prevalence of smoking in Indonesian keeps increasing. The prevalence of tobacco use among population over 15 years old increased from $27 \%$ in 1995 to $36.3 \%$ in $2013[6,7]$.
Smoking cessation is very challenging, effective intervention methods are needed to encouraging smokers to stop. Religiosity had been proven as predictor of smoking cessation $[8,9,10]$. Religion has important role in regulating what people done in their life, included practicing health behavior. Most religions regulate their members to avoid everything that have negative or harmful effect, such tobacco use $[8,11,12]$. People who have a good involvement in their religious activity are less likely having tobacco dependence $[9,13,14]$.

People who had greater religious attendance had more intention to discontinue their smoking habit. It increased the chance in smoking cessation till $40 \%$ [9]. Study among African American reported that more religious men had lower odds of being smoker (OR $0.21 ; 95 \% \mathrm{CI}$ 0.07 - 0.62) [15].

Indonesia is diversity country, not only have numerous cultures, ethnicity, languages, values, but it's also well known as religious country. Almost all the 
citizens have a religion and majority of them are Muslim [16]. Having faith in religion could be the guidance to act better in the daily life, such as encouraging people to stop smoking. The role of religiosity on discontinuing smoking habit is not addressed enough. The national scale research is needed to explore it. Therefore, this study was aimed to identify the relationship between religion and smoking cessation among the largest smoker population, those are working age population.

\section{METHOD}

This study used cross-sectional design. Data were obtained from The Fifth Wave of Indonesian Family Life Survey (IFLS 5) that conducted between late October 2014 and the end of April 2015. The IFLS 5 was a continuation of IFLS which first conducted in 1993. For this study, data from working age group (respondents whose age were $15-64$ years old) who ever or current smoke in IFLS 5 were obtained. The number of respondents was 11425 people. After excluding those respondents with missing data, 10481 respondents were included for analysis.

Smoking cessation was assessed by household survey questionnaire for the 5th IFLS, section KM04 (smoking behavior) [17]. The respondents were asked whether they still have the habit or have totally quit smoking. The respondents were coded as quitter if they answered "quit" and coded as current user if they answered "still have".

Religiosity was measured by asking respondents to answer the question in section TR11 (trust) [17]. The question was "How religious are you?". The responses were very religious, religious, somewhat religious, and not religious.

Covariates in this study included age, sex, marital status, education, working status, ethnic, smoking habit, and religion. Age categories were "15-25", "26-45", and "46-64" years. Sex categories were male and female. Marital status was coded as "not yet married", "married", and "others" which included separated, divorced, and widowed respondents. Educational level was measured by asking respondent about their highest level of education attended and divided into "elementary school", "middle high school", "senior high school", and "college". Working status was classified as "yes" and "no". The ethnicity of respondents was grouped into "Sundanese", "Batak", "Javanese", "Betawi", "Madurese", and "others". Smoking habit was categorized based on how many cigars/cigarettes did respondents consume in a day. Light smoker was defined as smoking 1-10 cigarettes/day, moderate smoker was classified as smoking 11-20 cigarettes/day, and respondents were categorized as heavy smoker, if they consume more than 20 cigarettes/day [18]. Religion was coded as "Islam", "Catholic", "Protestant", "Hindu", "Budha", and "Konghucu".
All variables were described using descriptive statistics and presented with number and percentages. Association between religiosity, other covariates, and smoking cessation status were evaluated by calculating odds ratios (OR) with Pearson Chi-square test. We performed multivariate logistic regression to assess the association of religiosity and smoking cessation with 95\% confidence interval (CI). All analyses were done with SPSS for Windows version 23.0 (SPSS, Chicago, IL, USA).

\section{RESULTS}

\subsection{Characteristics of Respondents}

This study included 10481 respondents. Most of them were male $(95.4 \%)$ and more than half the respondents were 26-54 years old $(54.7 \%)$. Based on their marital status, $77.8 \%$ respondents had been married. Respondents who had occupation or had working status were $66.6 \%$. In term of educational level, we could see broad disparity. The percentage of respondents who had been graduated from senior high school and college was quite high $(45.4 \%)$, but we could also find that respondents who only graduated from elementary school reached $31 \%$. Majority of respondents had Islam as their religion $(90.1 \%)$ and $38.5 \%$ were Javanese people (Table 1).

This study found that more than half respondents rated their religiosity level as religious person (53.8\%). Based on the amount of cigarettes consumed, most of respondents categorized as light smokers $(41.5 \%)$ and moderate smokers $(46.4 \%)$. The rates of respondents who reported as quitter were relatively low, only $11.4 \%$ had discontinued smoking (Table 1). The average age of quitting smoking was 34.55 years old.

Table 1. Frequency distribution of respondent's characteristic $(n=10481)$

\begin{tabular}{|l|l|l|}
\hline Variable & Frequency (n) & Percent (\%) \\
\hline Sex & & \\
Male & 9999 & 95.4 \\
Female & 482 & 4.6 \\
\hline Age & & \\
15-25 years old & 1846 & 17.6 \\
26-45 years old & 5730 & 54.7 \\
46-64 years old & 2905 & 27.7 \\
\hline Marital status & & \\
Not yet married & 1893 & 18.1 \\
Married & 8150 & 77.8 \\
Others & 438 & 4.2 \\
\hline Working status & & \\
No & 3503 & 33.4 \\
Yes & 6978 & 66.6 \\
\hline Educational level & & \\
Elementary & 3252 & 31.0 \\
school & & \\
Middle high & 2225 & 21.2 \\
school & & 34.3 \\
\hline
\end{tabular}




\begin{tabular}{|l|l|l|}
\hline Variable & Frequency (n) & Percent (\%) \\
\hline Senior high & & \\
school & 1159 & 11.1 \\
College & 247 & 2.4 \\
No answer & & \\
\hline Religion & & \\
Islam & 9441 & 90.1 \\
Catholic & 125 & 1.2 \\
Protestant & 435 & 4.2 \\
Hindu & 464 & 4.4 \\
Budha & 15 & 0.1 \\
Konghucu & 1 & 0.0 \\
\hline Type of smoker & & \\
Light smoker & 4348 & 41.5 \\
Moderate smoker & 4860 & 46.4 \\
Heavy smoker & 1152 & 11.0 \\
No answer & 121 & 1.2 \\
\hline Ethnic & & \\
Sunda & 1259 & 12.0 \\
Batak & 472 & 4.5 \\
Jawa & 4034 & 38.5 \\
Betawi & 484 & 4.6 \\
Madura & 241 & 2.3 \\
Others & 3991 & 38.1 \\
\hline Religiosity & & \\
Very religious & 1624 & 15.5 \\
Religious & 5640 & 53.8 \\
Somewhat & 2739 & 26.1 \\
religious & 478 & 4.6 \\
Not religious & & \\
\hline
\end{tabular}

\begin{tabular}{|l|l|l|}
\hline Variable & Frequency (n) & Percent (\%) \\
\hline $\begin{array}{c}\text { Smoking cessation } \\
\text { Yes }\end{array}$ & 1198 & \\
No & 9283 & 11.4 \\
\end{tabular}

\subsection{Association With Smoking Cessation}

Female had higher proportion in quitting smoking than male $(21.4 \%$ and $11.0 \%$, OR $2.210,95 \%$ CI $1.762-$ 2.772). Older people also showed progressive reduction in smoking dependency. People over 45 years old were almost 3 times to cease from their smoking habit than those aged 15-25 years old (OR 2.869; 95\% CI $2.339-$ 3.518). Among unmarried people, only $6.8 \%$ of them stated that they had totally stop smoking. The smoking cessation was more likely performed by married people as well as working people $(\mathrm{P}<0.001)$. We found significant association between educational level and decision to stop smoking $(\mathrm{P}<0.001)$. In term smoking habit, Catholics showed lower dependency in smoking, $19.2 \%$ of them declared that they weren't smoker anymore. Smoking cessation among Muslim was $10.9 \%$. We could see the different proportion of smoking cessation among religion $(\mathrm{P}<0.001)$. Ethnicity and type of smoker also had significant association with smoking cessation $(\mathrm{P}<0.001)$. The Madurese and heavy smoker had higher proportion in discontinuing tobacco smoking than others (Table 2).

Table 2. Bivariate analysis of factors associated with smoking cessation among working age population in Indonesia

\begin{tabular}{|c|c|c|c|c|c|c|}
\hline \multirow[t]{3}{*}{ Variable } & \multicolumn{4}{|c|}{ Smoking cessation } & \multirow[t]{3}{*}{ OR $(95 \% \mathrm{CI})$} & \multirow[t]{3}{*}{ p-value } \\
\hline & \multicolumn{2}{|c|}{ Yes } & \multicolumn{2}{|c|}{ No } & & \\
\hline & $\mathbf{n}$ & $\%$ & $\mathbf{n}$ & $\%$ & & \\
\hline $\begin{array}{l}\text { Religiosity } \\
\text { Very religious } \\
\text { Religious } \\
\text { Somewhat religious } \\
\text { Not religious }\end{array}$ & $\begin{array}{l}220 \\
721 \\
229 \\
28\end{array}$ & $\begin{array}{l}13.5 \\
12.8 \\
8.4 \\
5.9\end{array}$ & $\begin{array}{l}1404 \\
4919 \\
2510 \\
450\end{array}$ & $\begin{array}{l}86.5 \\
87.2 \\
91.6 \\
94.1\end{array}$ & $\begin{array}{l}2.52(1.68-3.79) \\
2.36(1.60-3.48) \\
1.47(0.98-2.20) \\
\operatorname{Ref}\end{array}$ & $0.000 * *$ \\
\hline $\begin{array}{l}\text { Sex } \\
\text { Female } \\
\text { Male } \\
\end{array}$ & $\begin{array}{l}103 \\
1095\end{array}$ & $\begin{array}{l}21.4 \\
11.0 \\
\end{array}$ & $\begin{array}{l}379 \\
8904\end{array}$ & $\begin{array}{l}78.6 \\
89.0 \\
\end{array}$ & $2.21(1.76-2.77)$ & $0.000 * *$ \\
\hline $\begin{array}{l}\text { Age } \\
46-64 \text { years old } \\
26-45 \text { years old } \\
15-25 \text { years old }\end{array}$ & $\begin{array}{l}508 \\
563 \\
127\end{array}$ & $\begin{array}{l}17.5 \\
9.8 \\
6.9\end{array}$ & $\begin{array}{l}2397 \\
5167 \\
1719\end{array}$ & $\begin{array}{l}82.5 \\
90.2 \\
93.1\end{array}$ & $\begin{array}{l}2.87(2.34-3.52) \\
1.48(1.21-1.80) \\
\text { Ref }\end{array}$ & $0.000 * *$ \\
\hline $\begin{array}{l}\text { Marital status } \\
\text { Married } \\
\text { Others } \\
\text { Not yet married }\end{array}$ & $\begin{array}{l}1015 \\
54 \\
129 \\
\end{array}$ & $\begin{array}{l}12.5 \\
12.2 \\
6.8\end{array}$ & $\begin{array}{l}7132 \\
387 \\
1764\end{array}$ & $\begin{array}{l}87.5 \\
87.8 \\
93.2\end{array}$ & $\begin{array}{l}1.95(1.61-2.35) \\
1.91(1.36-2.67) \\
\text { Ref }\end{array}$ & $0.000^{* *}$ \\
\hline $\begin{array}{l}\text { Working status } \\
\text { Yes } \\
\text { No }\end{array}$ & $\begin{array}{l}884 \\
314 \\
\end{array}$ & $\begin{array}{l}12.7 \\
9.0\end{array}$ & $\begin{array}{l}6094 \\
3189\end{array}$ & $\begin{array}{l}87.3 \\
91.0\end{array}$ & $1.47(1.29-1.69)$ & $0.000 * *$ \\
\hline $\begin{array}{l}\text { Educational level } \\
\text { College } \\
\text { Senior high school } \\
\text { Middle high school } \\
\text { Elementary school } \\
\end{array}$ & $\begin{array}{l}234 \\
374 \\
224 \\
338\end{array}$ & $\begin{array}{l}20.2 \\
10.4 \\
10.1 \\
10.4\end{array}$ & $\begin{array}{l}925 \\
3224 \\
2001 \\
2915\end{array}$ & $\begin{array}{l}79.8 \\
89.6 \\
89.9 \\
89.6\end{array}$ & $\begin{array}{l}2.18(1.82-2.62) \\
1.00(0.86-1.17) \\
0.97(0.81-1.15) \\
\operatorname{Ref}\end{array}$ & $0.000 * *$ \\
\hline $\begin{array}{l}\text { Religion } \\
\text { Catholic } \\
\text { Protestant } \\
\text { Hindu }\end{array}$ & $\begin{array}{l}24 \\
66 \\
79\end{array}$ & $\begin{array}{l}19.2 \\
15.2 \\
17.0\end{array}$ & $\begin{array}{l}101 \\
369 \\
385\end{array}$ & $\begin{array}{l}80.8 \\
84.8 \\
83.0\end{array}$ & $\begin{array}{l}1.95(1.24-3.05) \\
1.46(1.12-1.92) \\
1.68(1.31-2.16)\end{array}$ & $0.000 * *$ \\
\hline
\end{tabular}




\begin{tabular}{|c|c|c|c|c|c|c|}
\hline \multirow[t]{3}{*}{ Variable } & \multicolumn{4}{|c|}{ Smoking cessation } & \multirow[t]{3}{*}{ OR $(95 \%$ CI) } & \multirow[t]{3}{*}{ p-value } \\
\hline & \multicolumn{2}{|c|}{ Yes } & \multicolumn{2}{|c|}{ No } & & \\
\hline & $\mathbf{n}$ & $\%$ & $\mathbf{n}$ & $\%$ & & \\
\hline Budha & 1 & 6.7 & 14 & 93.3 & $0.59(0.08-4450)$ & \\
\hline Konghucu & & 0.0 & & 100.0 & 0.00 & \\
\hline Islam & 1029 & 10.9 & 8413 & 89.1 & Ref & \\
\hline Type of smoker & & & & & & $0.000 * *$ \\
\hline Heavy smoker & 196 & 17.0 & 956 & 83.0 & $1.51(1.27-1.81)$ & \\
\hline Moderate smoker & 470 & 9.7 & 4390 & 90.3 & $0.79(0.69-0.90)$ & \\
\hline Light smoker & 519 & 11.9 & 3829 & 88.1 & Ref & \\
\hline Ethnic & & & & & & $0.001^{* *}$ \\
\hline Batak & 49 & 10.4 & 423 & 89.6 & $1.39(0.97-1.99)$ & \\
\hline Jawa & 471 & 11.7 & 3563 & 88.3 & $1.58(1.26-1.99)$ & \\
\hline Betawi & 57 & 11.8 & 427 & 88.2 & $1.60(1.13-2.26)$ & \\
\hline Madura & 32 & 13.3 & 209 & 86.7 & $1.83(1.20-2.81)$ & \\
\hline Others & 492 & 12.3 & 3499 & 87.7 & $1.68(1.34-2.12)$ & \\
\hline Sunda & 97 & 7.7 & 1162 & 92.3 & Ref & \\
\hline
\end{tabular}

\subsection{Religiosity And Smoking Cessation}

Religiosity level had significantly related with smoking cessation. Religious persons had greater chance to stop smoking. The final model of multiple logistic regression showed that very religious people, religious, and somewhat religious were less likely to smoke than not religious people. They had greater intention to quit smoking (Table 3).

Table 3. Association between religiosity and smoking cessation by multiple logistic regression

\begin{tabular}{|c|c|c|c|}
\hline Variables & aOR & $95 \% \mathrm{CI}$ & Sig. \\
\hline \multicolumn{4}{|l|}{ Religiosity } \\
\hline Not religious & Ref & & \\
\hline Somewhat religious & 1.33 & $0.88-2.01$ & 0.177 \\
\hline Religious & 1.83 & $1.23-2.72$ & $0.003 * *$ \\
\hline Very religious & 1.99 & $1.31-3.02$ & $0.001 * *$ \\
\hline Sex & 2.64 & $2.03-3.44$ & $0.000 * *$ \\
\hline \multicolumn{4}{|l|}{ Age } \\
\hline $15-25$ yesrs old & Ref & & \\
\hline $26-45$ years old & 1.13 & $0.88-1.46$ & 0.330 \\
\hline 46-64 years old & 2.22 & $1.69-2.91$ & $0.000 * *$ \\
\hline Working status & 1.21 & $1.01-145$ & $0.039 * *$ \\
\hline \multicolumn{4}{|l|}{ Educational level } \\
\hline Elementary school & Ref & & \\
\hline Middle high school & 1.31 & $1.09-1.59$ & $0.004 * *$ \\
\hline Senior high school & 1.37 & $1.16-1.62$ & $0.000 * *$ \\
\hline College & 2.67 & $2.20-3.24$ & $0.000 * *$ \\
\hline \multicolumn{4}{|l|}{ Religion } \\
\hline Islam & Ref & & \\
\hline Catholic & 1.93 & $1.20-3.12$ & $0.007 * *$ \\
\hline Protestant & 1.66 & $1.17-2.35$ & $0.005 * *$ \\
\hline Hindu & 1.41 & $1.06-1.88$ & $0.017 * *$ \\
\hline Budha & 0.35 & $0.04-2.84$ & 0.329 \\
\hline Konghucu & 0.00 & $0.000-$ & 1.000 \\
\hline \multicolumn{4}{|l|}{ Type of smoker } \\
\hline Light smoker & Ref & & \\
\hline Moderate smoker & 0.83 & $0.72-0.96$ & $0.008 * *$ \\
\hline Heavy smoker & 1.47 & $1.22-1.78$ & $0.000 * *$ \\
\hline \multicolumn{4}{|l|}{ Ethnic } \\
\hline Sunda & Ref & & \\
\hline Batak & 0.98 & $0.63-1.52$ & 0.911 \\
\hline Jawa & 1.72 & $1.35-2.18$ & $0.000 * *$ \\
\hline Betawi & 1.68 & $1.17-2.39$ & $0.004 * *$ \\
\hline
\end{tabular}

\begin{tabular}{|c|c|c|l|}
\hline Variables & aOR & 95\% CI & Sig. \\
\hline Madura & 1.88 & $1.19-2.98$ & $0.007 * *$ \\
Others & 1.62 & $1.28-2.06$ & $0.000^{* *}$ \\
\hline
\end{tabular}

\section{DISCUSSION}

This study found that the rate of smoking cessation among working age population was very low. It was less than the results of National Health Interview Surveys (NHIS) which conducted in the United States [19]. More than half adult smokers stop smoking in a past-year and who recently quit smoking was $7.4 \%$. Most of the smokers in the United Stated had intention to totally stop smoking [19]. In Korea, the adults aged 19 years or more also reported having strong attempt to quit smoking in the last year [20]. Having long-term dependency in tobaccouse made smokers getting difficulty to discontinue their smoking habit. They often experienced withdrawal symptoms that pressure them to start smoking again [21]. Most of Indonesian smokers had start smoking in early age, ranging from 12 to 13 [22]. Earlier in having the first cigarette, they tend to be a regular smoker and would escalate the number of cigarettes that smoked [23].

The smokers who stated that they had totally quit from smoking were greater among female. This finding was contradicted with the others studies [24,25]. Those studies reported that women were less likely to stop smoking than men. Women had harder situation in maintaining abstinence from smoking, so they had greater chance to relapse [25]. However, the large population studies found no different in smoking cessation rates among women and men [19,26]. This dissimilarity may be caused by the variation in samples, such in bio-psycho-social terms and patterns of smoking among women. Our study also showed that the quitter were more likely to be found among older people, higher educational level, married, heavy smoker, and worked. Older smokers are more motivated to quit smoking. This finding was similar with the population study in Taiwan. Rates of smoking cessation increased over the age group [27]. Educational level was consistent in influencing 
people to stop smoking. Some studies had reported that higher education having greater chance to be quitter than lower education. The difference in quitter rate among education groups are possible related with economic status and support systems in smoking cessation [19, 28].

Religiosity indicated significant association with smoking cessation. More religious people had higher chance to quit smoking than the less ones. These results are consistent with other studies that showed religiosity as predictor of smoking cessation $[8,9,10,15]$. Most religion teaches good values that guide people to be a good person. Religious people have stronger commitment to obey their religion's rules. They prefer avoiding something harmful than doing risky behavior, such as smoking which proven having negative effects on their health. They believe that their God always supervise them. It encourages them to do what religion said [8, 29].

Major limitation of this study was related to variable's measurements. Religiosity as well as smoking cessation was measured by single item. Both of them were based on respondent's perception only. The data could not represent whole aspects of religiosity and assured the respondent's response. Information bias may influence the results. The use of cross-sectional design could not determine the chronological changes in smoking habit as religiosity influence. However, the use of national survey data presented the strength of this study. It had a good inferential to the population. Large sample size increased the power of this study.

Future research could use longitudinal data from IFLS 1 to IFLS 5 to explore the directionally effect of religiosity in smoking cessation. Assessing religion activity as the indicator to measure the religiosity level may increase the validity. Further researches about factors related to smoking cessation are still needed. Better understanding of smoking cessation's predictors could be useful for designing effective intervention in tobacco control, especially smoking cessation program.

\section{CONCLUSION}

People who have higher level of religiosity tend to stop smoking. Including religious interpretation about the risk of tobacco use on health promotion or smoking cessation program should be a good alternative. It could increase the intention and encourage people to stop smoking.

\section{AUTHORS' CONTRIBUTIONS}

TDT contributed to design the study, search literature, analyze the data, interpret data, writing the original manuscript and revise the manuscript. EA \& NHU conducted the literature search, made critical feedback, and revise the manuscript. All authors read and approved the final manuscript.

\section{ACKNOWLEDGMENTS}

The authors thank to RAND Corporation that provide IFLS 5 data as public domain and also to Faculty of Sport Science, Universitas Negeri Malang that support this study.

\section{REFERENCES}

[1]. World Health Organization. Tobacco, 2018 [cited 9 September 2018]. Available from: http://www.who.int/news-room/factsheets/detail/tobacco.

[2]. National Center for Chronic Disease Prevention and Health Promotion (US) Office on Smoking and Health. The Health Consequences of Smoking - 50 Years of Progress: A Report of the Surgeon General. Atlanta (GA): Centers for Disease Control and Prevention (US), 2014 [cited 9 September 2018]. Available from: https://www.ncbi.nlm.nih.gov/books/NBK29431 $6 /$.

[3]. Australian Institute of Health and Welfare 2016. Australia's health 2016. Australia's health series no. 15. Cat. no. AUS 199. Canberra: AIHW.

[4]. World Health Organization. Indonesia Tobacco Factsheet 2018, 2018 [cited 9 September 2018]. Available from http://www.who.int/iris/bitstream/10665/272673/ 1/wntd_2018_indonesia_fs.pdf.

[5]. J. Britton. Death, disease, and tobacco. The Lancet, 2017, pp.1861-1862. DOI: https://doi.org/10.1016/S0140-6736(17)30867-X

[6]. Badan Pusat Statistik. Survei Sosial Ekonomi Nasional (SUSENAS) Tahun 1995. Jakarta: BPS, 1996.

[7]. Badan Penelitian dan Pengembangan Kesehatan Kementerian Republik Indonesia. Riset Kesehatan Dasar (Riskesdas) Tahun 2013. Jakarta: Balitbang Kemenkes RI, 2013.

[8]. B. Garussi, N. Nakhaee. Religion and smoking: a review of recent literature. The International Journal of Psychiatry in Medicine, 2012, pp. 279292. DOI: https://doi.org/10.2190/PM.43.3.g

[9]. Q.L. Brown, S.L. Linton, P.T. Harrell, et al. The influence of religious attendance on smoking. Substance Use \& Misuse, 2014, pp. 1392-1399. DOI:https://doi.org/10.3109/10826084.2014.912 224

[10]. H.H. Yong, S. Savvas, R. Borland, et al. Secular versus religious norms against smoking: which is more important as a driver of quitting behaviour among Muslim Malaysian and Buddhist Thai smokers?. International Journal of Behavioral 
Medicine, 2013, pp. 252-258. DOI: https://doi.org/10.1007/s12529-012-9225-6

[11]. World Health Organization. Tobacco Free Initiative: Meeting on Tobacco and Religion, 1999 [9 September 2018]. Available from http://www.who.int/tobacco/media/en/religionen g.doc

[12]. M.A. Whooley, A.L. Boyd, J.M. Gardin, D.R. Williams. Religious involvement and cigarette smoking in young adults: the CARDIA study. Archive of Internal Medicine, 2002, pp. 16041610.DOI: 10.1001/archinte.162.14.1604

[13]. N. Kungskulniti, N. Charoenca, T. Kengganpanich, et al. Smoking prevalence among monks in Thailand. Evaluation \& Health Professions, 2011, pp. 201-215. DOI: https://doi.org/10.1177\%2F0163278711426424

[14]. M.K. Sharma, L.N. Suman, M. Manjula, et al. Exploring the Role of Religion in Smoking Cessation. Delhi Psychiatry Journal, 2011, pp. 129-132.

[15]. J.V. Bowie, L.J. Parker, M. Beadle-Holder, et al. The influence of religious attendance on smoking among Black Men. Substance Use \& Misuse, 2017, pp. 581-586. DOI: https://doi.org/10.1080/10826084.2016.1245342

[16]. Badan Pusat Statistik. Sensus Penduduk 2010. Jakarta: Badan Pusat Statistik, 2011.

[17]. J. Strauss, F. Witoelar, B. Sikoki. Household Survey Questionnaire for the Indonesia Family Life Survey, Wave 5, 2016 [cited 1 September 2018]. Available from: https://www.rand.org/content/dam/rand/pubs/wor king_papers/WR1100/WR1143z3/RAND_WR11 43z3.pdf.

[18]. S. Shiffman, J.D. Kassel, J. Paty, et al. Smoking typology profiles of chippers and regular smokers. Journal of Substance Abuse, 1994, pp. 21-35. DOI: $\quad$ https://doi.org/10.1016/S08993289(94)90052-3

[19]. S. Babb, A. Malarche, G. Schauer, et al. Quitting smoking among adults-United States, 2000-2015. MMWR Morbidity \& Mortality Weekly Report, 2017, pp. 1457-1464. https://www.jstor.org/stable/24876523

[20]. D.W. Shin, B. Suh, S. Chun, et al. The Prevalence of and Factors Associated with the Use of Smoking Cessation Medication in Korea: Trend between 2005-2011. PLOS ONE, 2013, pp. e74904.

DOI: https://doi.org/10.1371/journal.pone.0074904.
[21]. U.S. Department of Health and Human Services How Tobacco Smoke Causes Disease: The Biology and Behavioral Basis for SmokingAttributable Disease: A Report of the Surgeon General. Atlanta: U.S. Department of Health and Human Services, Centers for Disease Control and Prevention, National Center for Chronic Disease Prevention and Health Promotion, Office on Smoking and Health, 2010 [cited 8 September 2018]. Available from: https://www.cdc.gov/tobacco/data_statistics/sgr/2 010/index.htm.

[22]. World Health Organization, Regional Office for South-East Asia. Global Youth Tobacco Survey (GYTS): Indonesia report, 2014. New Delhi: WHO-SEARO, 2015.

[23]. Bonnie, Richard J., and Barbara S. Lynch, eds. Growing up tobacco free: preventing nicotine addiction in children and youths. National Academies Press, 1994.

[24]. A.M. Allen, C. Oncken, D. Hatsukami. Women and smoking: the effect of gender on the epidemiology, health effects, and cessation of smoking. Current Addiction Reports, 2014, pp. 53-60. DOI: $10.1007 / \mathrm{s} 40429-013-0003-6$

[25]. P.H. Smith, A.J. Bessette, A.H. Weinberger, et al. Sex/gender differences in smoking cessation: a review. Preventive Medicine, 2016, pp. 135-140. DOI:https://doi.org/10.1016/j.ypmed.2016.07.01

[26]. E. Vangeli, J. Stapleton, E.S. Smit, et al. Predictors of attempts to stop smoking and their success in adult general population samples: A systematic review. Addiction, 2011, pp. 2110 2121. DOI:10.1111/j.1360-0443.2011.03565.

[27]. C.Y. Chiang, H.Y. Chang. A population study on the time trend of cigarette smoking, cessation, and exposure to secondhand smoking from 2001 to 2013 in Taiwan. Population Health Metrics, 2016 , 14.1: 38. DOI: https://doi.org/10.1186/s12963016-0109-x

[28]. Y.L. Zhuang, A.C. Gamst, S.E. Cummins, et al. Comparison of smoking cessation between education groups: findings from 2 US National Surveys over 2 decades. American Journal of Public Health, 2015, pp. 373-379. DOI: https://doi.org/10.2105/AJPH.2014.302222

[29]. M. Hussain, C. Walker, G. Moon. Smoking and religion: untangling associations using English survey data. Journal of Religion and Health, 2019, pp. 2263-2276. DOI: https://doi.org/10.1007/s10943-017-0434-9 